\title{
A Study of the Anatomy of Decision Making in the Planning and Appraisal of Hong Kong Section of Guangzhou-Shenzhen-Hong Kong High Speed Rail
}

\section{Junyou Liu*}

School of Architecture and Art, Central South University, Changsha 410075, China

\begin{abstract}
This paper will study the anatomy of the decision making of Hong Kong Section of Guangzhou-Shenzhen-Hong Kong High Speed Rail (XRL). The paper will focus on five aspects. They are drivers of megaprojects, mega infrastructure project as an agent of change, early and effective stakeholder engagement, Iron Triangle and context awareness. XRL will be regarded as a resonance test of the international literature findings.
\end{abstract}

Key words: Decision making; Anatomy; Risk

Publication date: May, 2021; Publication online: 31 May, 2021

*Corresponding author: Junyou Liu, 531623827@qq.com

\section{Introduction}

Megaprojects are defined as projects which cost a billion US dollars or more at 1999 prices $^{[1]}$. This paper will study the anatomy of the decision making in the planning and appraisal of XRL. Firstly, this paper will critically review international literature in this field. The case study will be based on the critical literature reviews. The resonance test of the project will be conducted.

\section{Literature review}

Mega transport projects have multiple environmental, economic, spatial, and other implications. They frequently become crucial 'agents of change'. However, decision-makers often under-appreciated their ability to change the context $t^{[1]}$. Project can only be thought as successful, when it measured against varies criteria such as social impact, economic impact and environmental impact ${ }^{[2]}$. This paper thinks this assessment can help to examine the role of these projects as an agent of change. Four sublimes drive megaproject boom and make megaproject attractive to decision makers. They are technical sublime, political sublime, economic sublime and aesthetical sublime. Technological sublime generally means pushing the boundaries for what technology can do. Political sublime means building monument for politicians and their influence.
Economic sublimes highlights business people and trade union earn money and get jobs from megaprojects. Aesthetic sublime focuses on the appearance and good design of Megaprojects. These make many stakeholders benefit from it and work for $\mathrm{it}^{[3]}$.

During the Mega urban transport project planning and delivery stage, it is crucial that there is a clearly identified public sector agency clearly tasked with taking a multi-function or multi-discipline view of roles, functions and implementation needs associated with the project development. This can avoid project planning and delivery reflect departmental or professional siols such as the Transport Department mainly consider transport matters, other departments may insert wider considerations ${ }^{[2]}$. Sponsors are the guiding hand for the projects. They provide resource, shape, anchors, and strategic direction. Projects have to meet sponsors' objectives. Because they do not have perfect knowledge, and need to engage with stakeholders to identify a project. The role of planners is to identify a project and ensure the project has a good Business case, is adaptable to future change and is intensely supported. Because of the high cost of major project, the planner is placed a heavy reasonability to develop a suitable appraisal ${ }^{[4]}$.

Early and effective engagement with stakeholders is thought as critical for megaproject. This is effective for the 
treatment of risk of the project. Omega centre (2011) stated all key stakeholders should be involved in setting project objectives in one lesson of its study ${ }^{[2]}$. This can contribute to consensus in decision making. It is less effective that project promoters negotiate with stakeholders after objectives have been $\operatorname{set}^{[1]}$. More respectful and balanced relationship between the experts and lay communities are good ${ }^{[5]}$. Risk can be shared between different stakeholders ${ }^{[1]}$. Lay people are helpful for effective hazard management. However, some people criticize community involvement lead to project delay and focus on NIMSY(not in my backyard) issue.

Iron Triangle of project performance is a wide used criteria of finishing mega-project on time, within budget and specification have not prevailed as the overriding criteria for successful project. Although some projects finished on time within budget and specification, in broader term, they may finish at the wrong time, in the wrong place serving only a narrow set of stakeholders and generate unsustainable outcomes. Due to different perception, some projects were claimed by others as 'failure' are now seen as 'successes ${ }^{\text {'[6] }}$. Cost overrun is common for Megaprojects. Based on large data set of major projects, project delay causes cost overrun and benefit shortfall. One year delay correlate with 4.64 percent cost overrun. Keep implementation stage short and delay small is thought as effective for keeping cost down. Many Megaprojects suffer from the problem of overestimated benefit. Up to $50 \%$ benefit shortfalls are common. Because of cost overrun and benefit shortfall, many appraisal methods like Business case, Cost-benefit analysis, Social and Environmental Impact Assessment cannot be trusted ${ }^{[3]}$.

Context has varied dimensions. Several contexts which thought as having great influence on megaprojects in 21 century are Unstable economic circumstance, new technology, energy concern and climate change and the extended time required in completing MUTP planning and development process. Decision makers have to be sensitive about the context which the project will be delivered. It can decide the successes of the project. Context awareness is crucial for the treatment of contextual risk. Planners have to be context sensitive ${ }^{[2]}$.

\section{Case study}

The map 1 shows the route of XRL. The XRL is an approximately $26 \mathrm{KM}$ long underground high speed rail route in Hong Kong. The XRL runs from west Kowloon Station in Hong Kong. It connects with the Mainland China High-speed rail network. The operation of the high-speed rail service began on 23 September 2018. The last estimated project cost was HK dollar 84.42 billion (roughly 10.97 billion US dollars) ${ }^{[7]}$. The Megaproject includes the tunnel and the underground rail link and Hong Kong West Kowloon Station ${ }^{[8]}$.

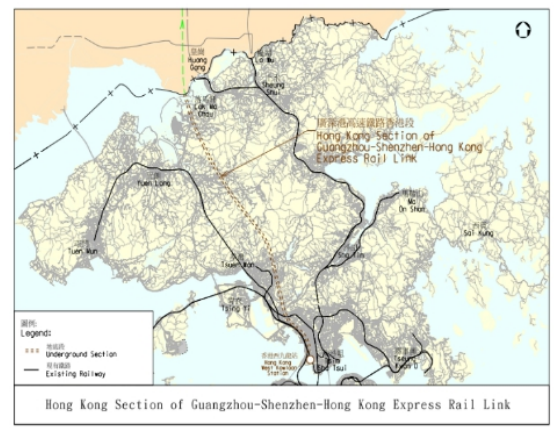

Figure 1. Hong Kong Section of Guangzhou-Shenzhen-Hong Kong High speed rail

Politicians think the connection is beneficial for the social and economic development of Hong Kong ${ }^{[9]}$. Economic sublime is a drive force for the project. Before the planning of XRL, an ordinary train rail link (Train speed $80 \mathrm{KM} / \mathrm{h}$ to $120 \mathrm{Km} / \mathrm{h}$ ) exists between Hong Kong and the mainland China. Decision makers believe high-speed rail as technical improvement is required. Political sublime also influenced the project. The administrative official of HKSAR Carrie Lam Cheng Yuet-ngor believes the project is not only beneficial for social and economic development but also improve people's livelihood ${ }^{[10]}$ (Figure 1).

The Sponsor of the project is the HKSAR Government. The HKSAR Government decided to build the high-speed rail to connect Hong Kong and mainland China. This shows sponsor is the guiding hand of the project. MTR Corporation Limited (MTRCL) was designated for the further planning and design of the XRL in 2008. Evidence shows MTRCL actively negotiated with other departments and district councils for the project. MTRCL also carried out Environmental Impact Assessment to identify the project meet the environmental needs pinpointed by the Environmental Department ${ }^{[8]}$. The MTRCL also played a role to avoid political departmental or professional siols. MTRCL as an identified public sector agency for XRL also played an active role in choosing contractors for further planning, appraisal and construction of the project and facilitated the agreement between different stakeholders. 
This negatively influenced the project ${ }^{[11]}$. This paper believes if planners can play a more active role about the early estimation of the project cost and benefit, the project may obtain more funding and not suffer from so serious cost overrun.

Table 1 shows key stakeholders of this megaproject. In 2005, Transport and Housing Bureau of HKSAR Government negotiated with the Ministry of Railway of mainland China. This early negotiation mainly occurred between these two authorities. This shows they did not have early and effective engagement with many stakeholders such as MTRCL, design corporations, communities. They did not hear much public opinions about the project. In 2008, MTRCL was required to further plan and design this project. The community liaison group of the XRL project was established in 2010, when the project construction began. Community liaison group did not play a role in the early stage. However, some consultation meetings occurred since MTRCL responsible for the project in 2008. The consultation between MTRCL and some HKSAR Government departments such as Transport and Housing bureau, Yuen Long District Council occur since MTRCL is responsible for the project. This paper thinks stakeholders involvement can be improved ${ }^{[8]}$.

Table 1. Key stakeholders of XRL

\begin{tabular}{|l|l|}
\hline Stakeholder & Role \\
\hline HKSAR government & Provide funding and regulate different aspects of the project \\
\hline Transport and Housing Bureau of HKSAR & Set policies and directions for Hong Kong' 'transportation sector \\
\hline MTRCL (This is a semi-privatised corporation) & Responsible for the design and construction of the project \\
\hline ARUP and Atkins China Ltd & Carry out the primary design of Hong Kong tunnel section for XRL \\
\hline $\begin{array}{l}\text { Construction Contractors (more than 10 contractors) such as ATAL } \\
\text { Engineering Ltd, Siemens Ltd, and Wan Chung Construction Co. Ltd }\end{array}$ & Responsible for construction of the project \\
\hline Communities & Can express the opinion about the project \\
\hline Independent Board Committee & Examine the project and write report about the project \\
\hline Ministry of Railways (China) & Regulate different aspects of the project \\
\hline District councils & Negotiate with MTRCL about their opinions about the project \\
\hline
\end{tabular}

The initial agreement between HKSAR Government and MTRCL was the MTRCL obtain a funding of HK\$ 65 billion to finish the project by 4 August $2015^{[12]}$. However, the actual cost suffered from around HK \$ 20 billion cost overrun and the project suffered from serious delay, the real operation time of the project was September of $2018^{[8]}$. Cost overrun was a common problem for many previous Megaprojects. The HKSAR Government and MTRCL did not have a good estimation about the cost of the project. In addition, they did not take suitable measure to avoid the problem of cost overrun. This paper has pinpointed delay can contribute to or exacerbate cost overrun. The delay and cost overrun issues occurred again in this project. In addition, the project also did not finish within the specification of HK\$ 65 billion. Based on Iron Triangle, the HKSAR government and MTRCL was not quite successful [13]. This project is predicted to provide time saving value of HK\$ 80 billion in next 50 years $^{[14]}$. Many factors have been taken in to account when consider the alignment such as effect on community, land requirements and operational, safety, technical, geological aspects ${ }^{[8]}$. From these aspects, this may be a suitable time for the project to be constructed in Hong Kong.

HKSAR Government signed monument with Ministry of Railways (China) about the project before further construction this project ${ }^{[8]}$. This shows decision makers realized political context can influence the project. The XRL is built using taxpayers' money. This paper believes the public involvement can be improved in the early planning stage of the project. If the project does not have a good consideration about the social context, this project may suffer from negative influence such as public opposition. $\mathrm{XRL}$ is an underground rail link project. Thus, relevant stakeholders should notice specific underground space context may influence the project. Two other reasons caused the project delay were waters running in to the tunnel and malfunction of tunnel burning machine ${ }^{[14]}$. If MTRCL and relevant construction cooperation can value the context and be more effective in treating these risks during the planning and appraisal step, these negative outcomes may not happen.

\section{Conclusion}

Four sublimes (political, economic, technical and aesthetical) have been considered. Mega infrastructure project can play the role of agent of change and increase its attractiveness for decision makers. Early and effective engagement of different stakeholders before the objectives of the project set can make the objectives meet the needs of more stakeholders. A clearly identified public sector agency can avoid political departmental or professional siols, contribute to the agreement between different stakeholders and play a positive role in managing risk. Some projects may not meet the 
criteria of Iron Triangle. However, based other criteria such as whether it is finished at right time, in right place, contribute to sustainable outcome, they are successful. Context can seriously influence the project. Decision makers should have good context awareness.

\section{Disclosure statement}

The author declares no conflict of interest.

\section{References}

[1] OMEGA centre. Mega projects executive summary lessons for decision-makers: An analysis of selected international large-scale transport infrastructure projects. London: Bartlett School of Planning. University College London;2012.

[2] Omega. Omega Research Programme Uk Case Studies; Project And Country Findings. London, Omega centre of UCL;2011.

[3] Flyvbjerg B. What You Should Know About Megaprojects, and Why: An Overview[J]. Project Management Journal,2014,45(2):6-19.

[4] Allport R. Planning Major Project. London. Thomas Telford; 2010.

[5] Littau P. Managing Stakeholders in Megaprojects: The MS Working Group Report, COST European Cooperation in Science and Technology, University of Leeds, Leeds http://www.megaproject. eu/assets/exp/docs/ Managing Stakeholders in_Megapoects.pdf.

[6] Dimitriou H. Ward J. Wright P. Mega transport projects-Beyond the 'iron triangle': Findings from the OMEGA research programme, Progress in Planning,2013,86: $1-43$.

[7] MTR. Express Rail Link in Hong Kong. viewed November 2018, http://www.expressraillink.hk/en/database/xrl-in-hk.html.
[8] MTR. Express Rail Link. viewed November 272018 , http://www.expressraillink.hk/en/project-details/key-informa tion.html.

[9] MTR. Environmental Impact Assessment of Hong Kong Section of Guangzhou-Shenzhen-Hong Kong High Speed Rail Link. viewed November 27 2018, https://www.epd.gov.hk/eia/register/report/eiareport/eia 169 2009/EIA\%20Report/Main\%20Text/pdf/EIA\%20TOC.pdf,. [10] Xinhuanet. The Hong Kong section of the Guangzhou-Shenzhen-Hong Kong high-speed railway opened to traffic on $23^{\text {rd }}$--Hong Kong enters the era of high-speed rail. viewed November 28 2018, http://www.xinhuanet.com/gangao/2018-09/22/c_129959046. htm.

[11] MTR. MTR Corporation welcomes Government's decision on Guangzhou-Shenzhen-Hong Kong Express Rail Link, viewed $\quad$ November $27 \quad$ 2018, http://www.expressraillink.hk/pdf/en/press-release/mtrpressr elease-20080422.pdf.

[12] Anon. Construction work delays of XRL. viewed November 29 2018 , https://www.info.gov.hk/gia/general/201405/21/P201405210 325.htm.

[13] Government of the Hong Kong Special Administrative Region Transport Bureau. Railway Development Strategy 2000. viewed November 29 2018, https://www.thb. gov.hk/eng/psp/publications/transport/publications/rds.pdf.

[14] South China morning Post. The delays, inflated costs and legal wrangles that have plagued the MTR Corporation's Guanghzhou-Shenzhen-Hong Kong Express Rail,viewed November 29

2018.

https://www.scmp.com/news/hong-kong/hong-kong-econom $\mathrm{y} /$ article/2165217/delays-inflated-costs-and-legal-wrangles-h ave. 